\title{
Locally Advanced Unresectable Renal Cell Carcinoma
}

National Cancer Institute

\section{Source}

National Cancer Institute. Locally Advanced Unresectable Renal Cell Carcinoma. NCI

Thesaurus. Code C155699.

A renal cell carcinoma that has spread from its original site of growth to nearby tissues

or lymph nodes and is not amenable to surgical resection. 